\title{
Planktonic methane production and oxidation within the algal maximum of the pycnocline: seasonal fine-scale observations in an anoxic estuarine basin
}

\author{
John McN. Sieburth, Percy L. Donaghay \\ Graduate School of Oceanography, University of Rhode Island Bay Campus, Narragansett, Rhode Island 02882-1197, USA
}

\begin{abstract}
High resolution profiles of methane concentration and potential methane-oxidation rates were used to test the importance of in situ production and oxidation in controlling methane structure and dynamics in the southern anoxic basin of the Pettaquamscutt Estuary, Rhode Island, USA. Profiles conducted in both April and August showed low but increasing methane concentrations in the surface oxic layer, a minor maximum about $0.75 \mathrm{~m}$ above the $\mathrm{Eh}=0$ boundary, a methane minimum just above $\mathrm{Eh}=0$, and a rapid increase to a major maximum about $0.75 \mathrm{~m}$ below $\mathrm{Eh}=0$. Methane concentrations in both maxima increased between April and August while concentrations in the methane minimum decreased. This methane minimum in the suboxic zone was strongly associated with a minor oxygen maximum and a major peak in chlorophyll due to the oxygenic alga Euglena proxima. April incubations in the presence of added oxygen at $2{ }^{\circ} \mathrm{C}$ supported oxidation rates as high as $9 \% \mathrm{~d}^{-1}$ in and just below the methane minimum at the $\mathrm{Eh}=0$ boundary, due to psychrophilic methane-oxidation. Similar experiments conducted in August at $22^{\circ} \mathrm{C}$ showed a similar narrow peak in potential methaneoxidation rates in and just below the methane minimum at the Eh $=0$ boundary, suggesting that the boundary was now dynamicaily controlled by rapid mesophilic methane-oxidation. Analysis of the August incubations at $2^{\circ} \mathrm{C}$ showed a decline in methane at the depths of the major methane maximum for $4 \mathrm{~d}$, followed by a 4 dincrease in methane concentration at the same depths, due presumably to the exhaustion of dissolved oxygen and the cessation of the masking oxidation. These results indicate that the seasonal increase in the major methane maximum is generated in situ by psychrophilic methaneproduction, a production that is largely masked by a concomitant psychrophilic methane-oxidation. The shift from an initial dominance of methane-oxidation to a final dominance of methane-production in the same water sample bottles indicates just how sensitive the structure of the major methane maximum is to the bacterial processes of methanogenesis and methanotrophy, changes in water temperature, and oxygen inputs by in situ primary production and physical intrusions. Such processes have made it difficult to document a major production of methane in the pycnocline.
\end{abstract}

\section{INTRODUCTION}

A small but persistent peak in methane concentration has been repeatedly observed in the pycnocline of seasonally stratified oceanic waters (cf. Sieburth 1991). Among the possible mechanisms for this paradoxical anaerobic production of methane in an otherwise oxygenated sea is the possibility of reduced microniches (Scranton \& Brewer 1977, Burke et al. 1983), but evidence for this has been lacking (Rudd \& Taylor 1980) until recently. Schlegel \& Jannasch (1981) hypothesized that the occurrence of oxygen-hypersensitive anaerobes in otherwise aerobic habitats may be due to reduced microniches created by their aerobic bacterial consorts. The few studies that have cultured methanogens from the upper ocean (Oremland 1979, Cynar \& Yayanos 1991) have used chemically reduced media that were developed to enrich methanogens from anoxic mud. Such media would exclude the aerobic bacterial consorts of planktonic methanogens. In anoxic intertidal muds, methylotrophic methanogens that use the methylated amine degradation products of the algal 
osmolyte, glycine betaine, produce from 35 to $90 \%$ of the methane (Oremland et al. 1982, King et al. 1983. King 1984). The existence of methanogenic bacterial consortia that can use methylated amines to create reduced microniches in oxygenated seawater and produce both methane and hydrogen sulphide in the upper ocean was first reported by Sieburth (1987). These methanogenic bacterial consortia accompany algae into xenic culture (Sieburth 1988) and peak in the pycnocline (Sieburth 1993). In a study to observe the distribution of subpopulations of methylotrophic methanogens in the water column of the stratified Chesapeake Bay, USA, a conventional, chemically reduced methanogen medium (Sowers \& Ferry 1983) did well only up the estuary, while enrichments made from oxygenated seawater samples that were reduced by the oxidative bacterial consorts of the methanogens became dominant seaward (Sieburth 1993). The latter enrichment cultures that allow concomitant methanogenesis and methanotrophy in the oxic phase apparently act as surrogate algae and duplicate processes in the sea (Sieburth in press). Immunological fingerprinting of these dominant planktonic methanogens indicated that they all are new species and probably include new taxa that are distinct from benthic methanogens (Sieburth et al. 1993b). More detailed studies on the methane cycle in the water column of Chesapeake Bay were not practical due to time scale variations of estuarine stratification parameters (Tyler \& Seliger 1989), which preclude the resampling of the same vertical water column.

In order to further study the processes of the methane cycle in the pycnocline we chose a captive estuarine water column located very close to our laboratories that approaches an ideal habitat for studying the tight coupling between primary production and the processes of methane-production and methane-oxidation in the water column (Sieburth 1987, 1991). The pycnocline of the southern anoxic basin of the Pettaquamscutt Estuary, Rhode Island, USA (Gaines \& Pilson 1972, Gaines 1975), is dominated year round by the oxygenic alga Euglena proxima (Miller 1972). This permanently stratified and anoxic estuarine basin is effectively isolated from the northern basin by a $1 \mathrm{~m}$ sill and from the ocean by the shallow, narrow, $6 \mathrm{~km}$ long channel that connects it with the lower West Passage of Narragansett Bay. As a result, the dynamics in the oxic-anoxic transition zone (OATZ) occurring between 3 and $5 \mathrm{~m}$ in waters of the southern basin were dominated during the study period by in situ vertical processes, i.e. seasonal heating and cooling of the surface layer and vertical mixing of deep salty waters with fresh water inputs to the surface layer. Although advective processes that affect vertical structures can occur in this system (Donaghay et al. 1992), such advective effects appear to be restricted to episodic events.
Here we present observations on the seasonal variation in methane concentration and potential rates of methane-oxidation. They confirm our hypothesis of the essential role of oxygenic algae in the oxidation of methane in the upper reduced water column (Sieburth 1987). They also confirm our observations on methanogenic enrichment cultures (Sieburth 1993) that indicated that the production of methane in oxygenated seawater is masked by a concomitant oxidation of methane until dissolved oxygen is exhausted and methane is allowed to accumulate in the absence of methane-oxidation.

\section{METHODS AND MATERIALS}

All samples were collected from a floating platform (Donaghay et al. 1992) moored in the deepest part of the southern anoxic basin of the Pettaquamscutt Estuary, Rhode Island, USA (Fig. 1). The apparatus and

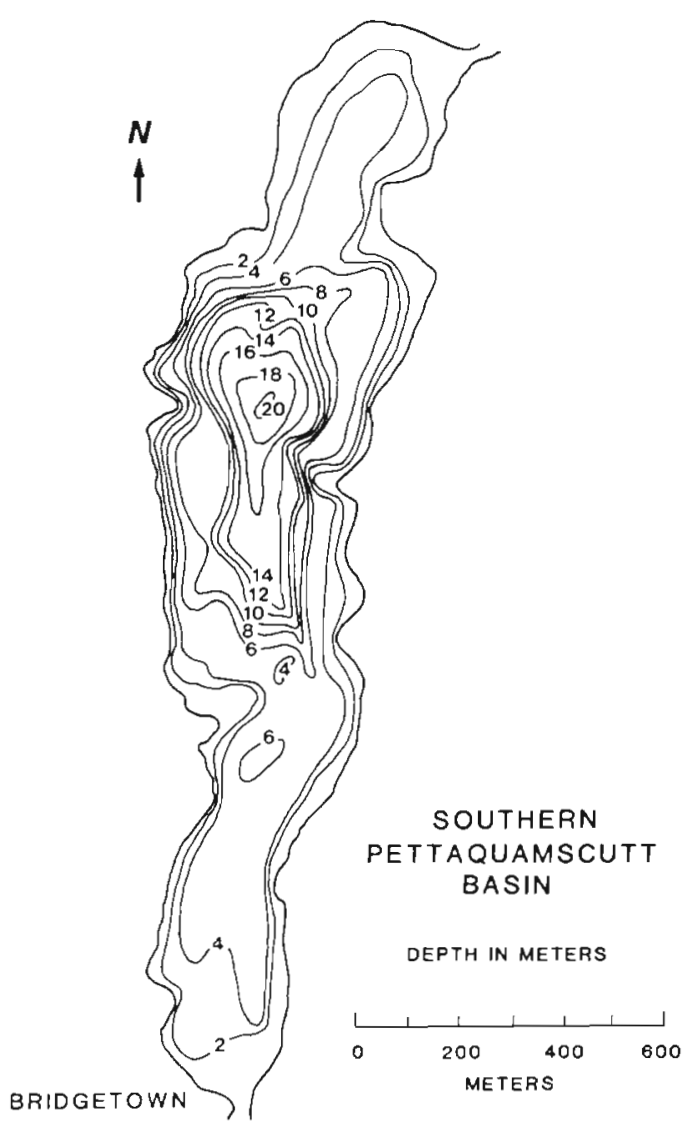

Fig. 1. Bathymetry of the southern anoxic basin of the Pettaquamscutt Estuary, Rhode Island. USA. Shallow sills at the Bridgeton Bridge to the south and at the connection to the northern anoxic basin create deep-water anoxia with an interface near $4 \mathrm{~m}$ where $\mathrm{Eh}=0$. The profiling and sampling platform is moored above the $20 \mathrm{~m}$ depression and the mooring lines keep it within the $18 \mathrm{~m}$ contour. (Figure from Gaines 1975) 
procedures for profiling and sampling were described by Donaghay et al. 1992). Briefly, vertical profiles of temperature, salinity, density, oxygen, $\mathrm{pH}$, Eh, light intensity, fluorescence, and light transmission were first collected at subcentimeter scales throughout the water column. Based on these profiles, 40 depths were chosen for discrete samples. Discrete samples, equivalent to the depths of the original profile, were collected by lowering the profiler to a specific density or light transmission value and then adjusting the vertical position of the profiler to stay within that specific reading in order to obtain siphoned samples of sufficient volume for chemical and microbiological analysis. All properties measured by the electronic profiler were recorded during siphon sampling to document the physical and chemical characteristics of the discrete samples collected for chemical and microbiological analysis. This procedure for tracking specific density or bio-optical layers was able to compensate for internal waves as large as $25 \mathrm{~cm}$. This allowed discrete samples for chemical and biological analysis to be collected from discrete layers at vertical scales as small as $5 \mathrm{~cm}$.

Three different types of samples for chemical analysis were collected at discrete depths. First, samples for $\mathrm{CH}_{4}$ were collected in $50 \mathrm{ml}$ serum bottles using the static headspace method of Johnson et al. (1990). All samples were kept on ice in the dark until returned to the laboratory, where the $\mathrm{CH}_{4}$ samples were equilibrated at a constant temperature prior to analysis. Second, when the oxygen electrodes showed that the oxygen concentration was undersaturated, replicate oxygen samples were collected for analysis by the zinc hydroxide modification of the Winkler method (Ingvorsen \& Jørgensen 1979). These samples were fixed inmediately, stored on ice in the dark and analyzed upon return to the lab. These samples were taken to provide a check on the in situ Sea Bird oxygen probe (Donaghay et al. 1992). Third, at each depth that a Winkler oxygen sample was drawn, samples for $\mathrm{H}_{2} \mathrm{~S}$ analysis by the procedure of Cline (1969) were collected and immediately fixed for later analysis.

Potential methane-oxidation rates were estimated with a modification of the bottle-calibration static headspace method for methane analysis (Johnson et al. 1990). In this procedure, $50 \mathrm{ml}$ serum bottles were filled with seawater from a given depth, and a calibrated pipette tip was used to replace $3.83 \pm 0.07 \mathrm{ml}$ of the water sample with air, before sealing with a serum stopper and crimped aluminum cap, and immediately taking each set of bottles to the lab. The samples obtained 26 April 1989 were incubated only at $2^{\circ} \mathrm{C}$ while replicates of the samples obtained 16 August 1989 were incubated at 2 and $22^{\circ} \mathrm{C}$, and $\mathrm{CH}_{4}$ concentrations were measured approximately every $2 \mathrm{~d}$ over an 8 to $12 \mathrm{~d}$ period. This allowed the indigenous methanotrophs capable of metabolism at the temperature of incubation to oxidize methane with the excess oxygen in the added air. The \% change in $\mathrm{CH}_{4}$ concentration was used as an index of potential methaneoxidation.

Water samples for microbiological analysis were preserved by the addition of glutaraldehyde (1\% final concentration), and refrigerated until processed. The direct microscopic enumeration of Euglena proxima Dangeard 1901 used recently collected preparations that were examined at $160 \times$ with phase contrast light microscopy, and counted the narrow $10 \times 75 \mu \mathrm{m}$ green pigmented cells on dried and immersion oil-cleared cellulosic filters using the $\mathrm{N}$-count program (Cynar et al. 1985). The bacterial plankton was obtained from discrete water samples from 20 October 1987, that were passed through a $20 \mu \mathrm{m}$ nytex screen, concentrated into pellets by centrifugation, embedded, thinsectioned, and examined by transmission electron microscopy (Sieburth et al. 1987)

\section{RESULTS}

\section{Vertical physical structure of the southern anoxic basin of the Pettaquamscutt Estuary}

The waters in the basin in April (Fig. 2a) were characterized by a shallow, low-salinity surface mixed layer, a very strong pycnocline that underwent a 13 sigma-theta change in $3 \mathrm{~m}$, and a deep pool of cool, high-salinity water below $4 \mathrm{~m}$. Between April and August 1989, the temperature of the surface mixed layer increased from 12.5 to $25^{\circ} \mathrm{C}$ while the halocline, thermocline, and pycnocline deepened (Fig. 2b). The strength of the pycnocline also increased during seasonal warming with maximum gradients rising from 0.18 to 0.29 sigmatheta $\mathrm{cm}^{-1}$. The temperature and salinity of the deep water (below $7 \mathrm{~m}$ ) remained remarkably constant over the 4 mo period at $8^{\circ} \mathrm{C}$ and $26.5 \mathrm{ppt}$, respectively, while water temperature at the upper limit for psychrophiles $\left(<20^{\circ} \mathrm{C}\right)$ extended to a depth of $4.25 \mathrm{~m}$. The strong pycnocline in this system is also a region of extremely sharp transitions in the chemical environment as indicated by changes in Eh potential. In April (Fig. 2a), for example, Eh changed from +34 to $-119 \mathrm{mV}$ in only $10 \mathrm{~cm}$ between 4.1 and $4.2 \mathrm{~m}$. The horizontal line at $4.2 \mathrm{~m}$ is the depth at which $\mathrm{Eh}=0$, and provides a repeatable reference point for the oxic-anoxic interface.

The particle structure of the water column showed relatively little change between April and August (Fig. 3). In both cases, vertical structure was dominated by 2 extremely narrow turbidity maxima in the steepest part of the pycnocline, the OATZ. The narrower upper particle extinction peak lacking a companion peak of 


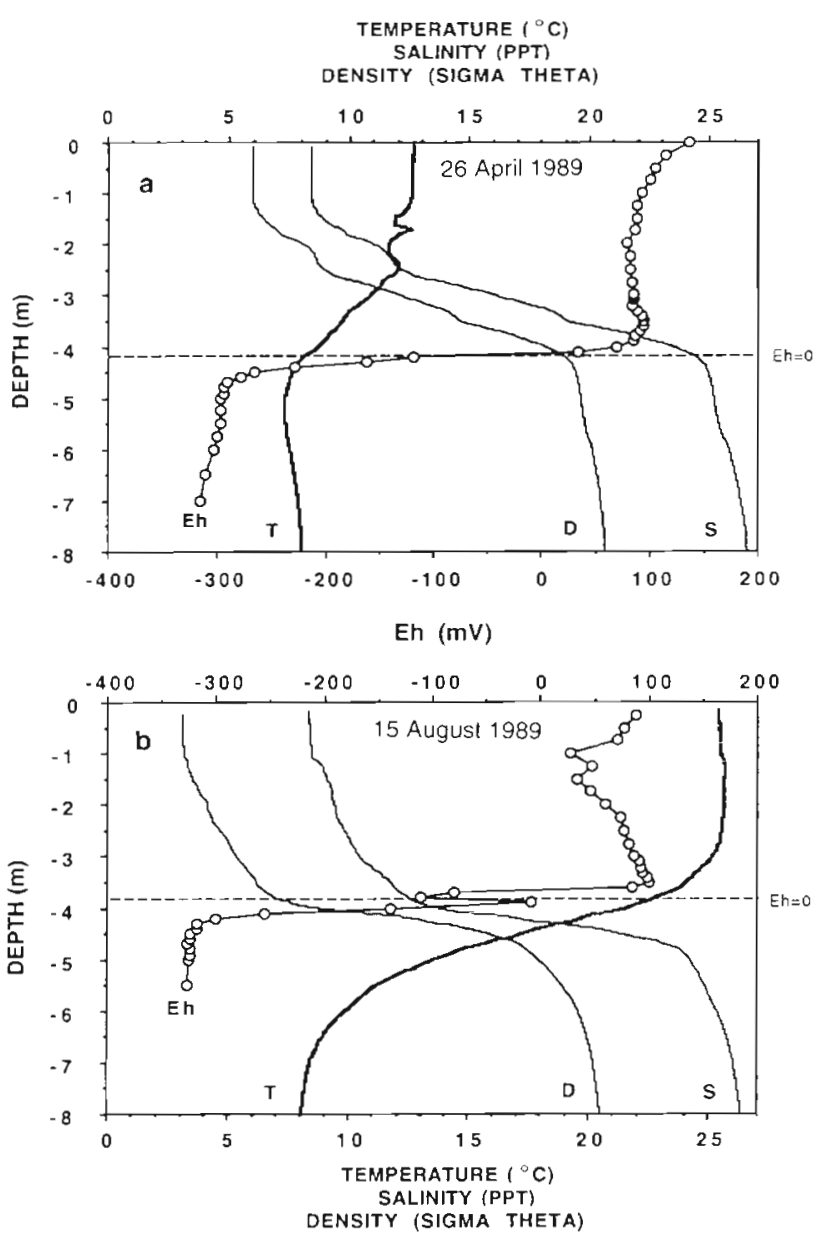

Fig. 2. Centimeter scale profiles of the physical structure (temperature, salinity and density) and the Eh potential for the upper $8 \mathrm{~m}$ of the southern anoxic basin of the Pettaquamscutt Estuary, obtained (a) 26 April and (b) 15 August 1989. Note that the water column in April up to the oxic-anoxic interface $(E h=0)$ was below $9^{\circ} \mathrm{C}$, the optimal temperature for obligate psychrophiles. Warming by August still did not exceed $20^{\circ} \mathrm{C}$ at $\mathrm{Eh}=0$, the maximal temperature for psychrophiles. The temperature in the mixing layer increased from 10.8 in April to $24.8^{\circ} \mathrm{C}$ in August thereby permitting mesophiles to develop

fluorescence was dominated by protozoan and metazoan grazers. The larger and broader lower particle extinction peak lay largely below the Eh boundary and coincided with a maximum in fluorescence. This large particle extinction peak is the zone of bacterial accumulation and activity, and its fluorescence is due to overlapping populations of an upper oxygenic green alga, Euglena proxima, and a lower undescribed spiral shaped brown-green anoxygenic photobacterium that uses $\mathrm{H}_{2} \mathrm{~S}$ for photosynthesis. This fluorescing particle maximum in the OATZ was so turbid that it reduced light transmission levels to extremely low values of 10 to $15 \% \mathrm{~m}^{-1}$, compared to the relatively low levels of 55 to $65 \% \mathrm{~m}^{-1}$ in the surface layer. This rapid absorption of light by the particle maxima is also reflected in a sharp bend in the slope of the photosynthetically active radiation vs. depth curve (Fig. 3a) and a decline in light levels to less than $1 \%$ of the surface by $4.5 \mathrm{~m}$.

\section{Methane, oxygen, and hydrogen sulfide structure in the OATZ}

Vertical profiles of methane, oxygen, and hydrogen sulphide were dominated by very sharp chemoclines that occurred in the pycnocline between 3.5 and $4.5 \mathrm{~m}$ (Fig. $4 \mathrm{a}, \mathrm{b}$ ). The slopes of the chemoclines for methane, oxygen, and hydrogen sulphide were very similar with a maximum rate of change that exceeded an order of magnitude in $20 \mathrm{~cm}$ for each of the 3 gases. Compared to the chemocline zone, the concentrations of the gases in the surface and bottom layers had slowly changing or relatively constant concentrations. A very important
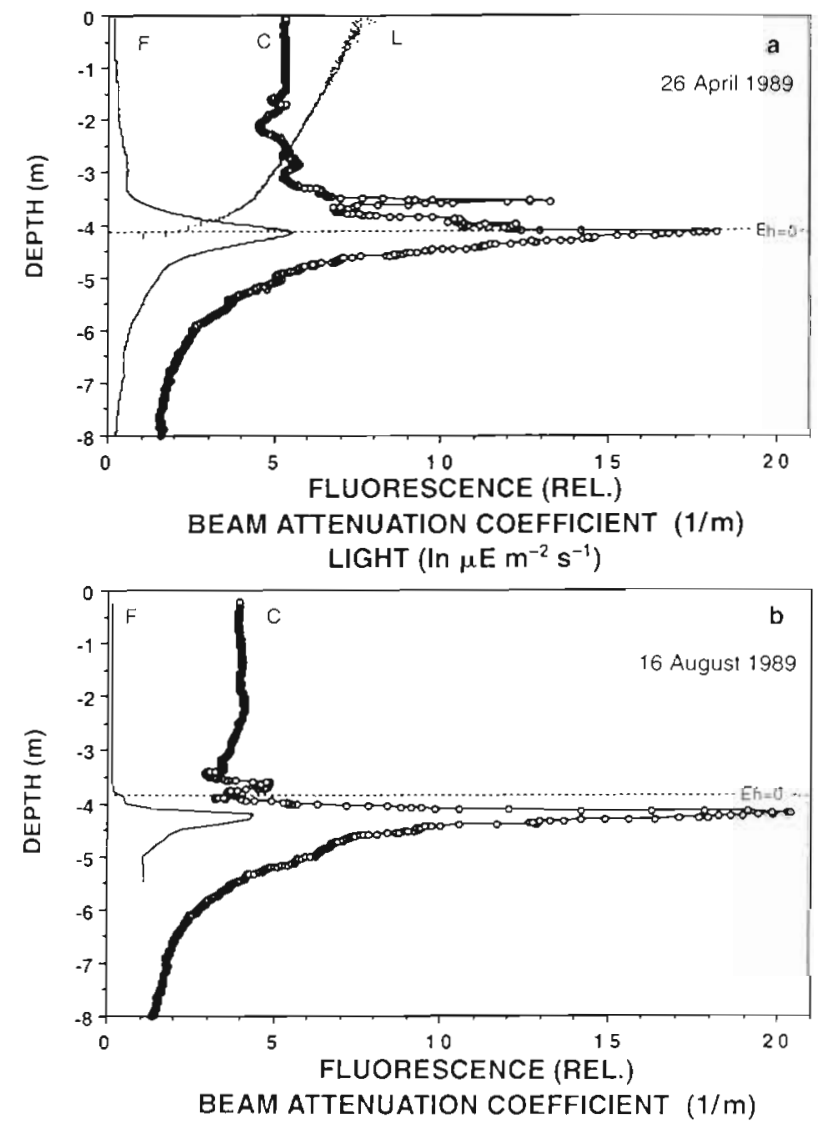

Fig 3. Centimeter scale profiles of particle structure (pigment fluorescence and extinction coefficient) for the upper $8 \mathrm{~m}$ of the southern anoxic basin of the Pettaquamscutt Estuary, obtained (a) 26 April and (b) 15 August 1989. The turbidity maximum is the limit of penetration of useful light. Note the single lower peak in fluorescence and the bimodal distribution of particles in the microbial accumulation zone 

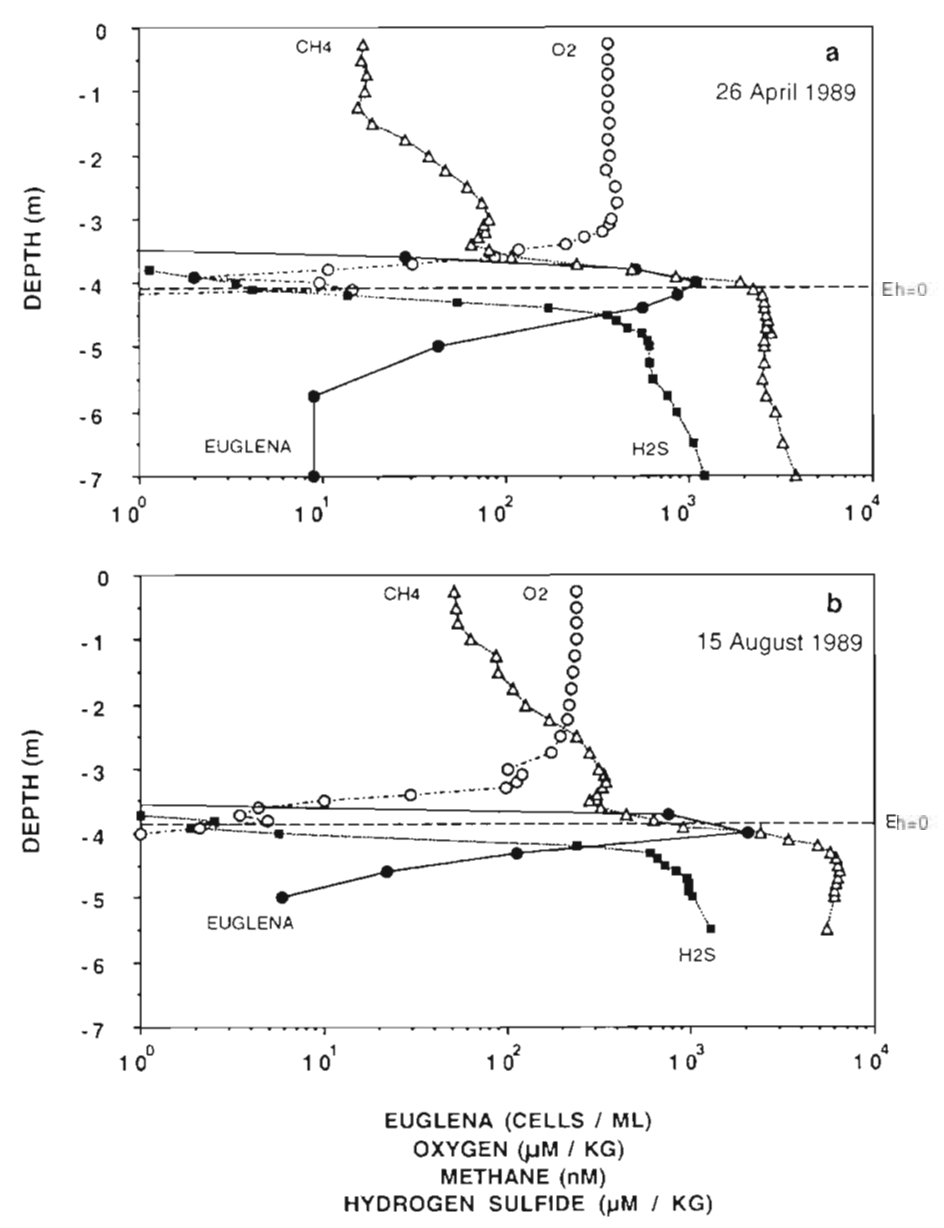

Fig. 4. Relationship of the large biomass of the oxygenic alga Euglena proxima to the distribution of oxygen and the reduced gases methane and hydrogen sulphide in the upper $7 \mathrm{~m}$ of the water column in the southern anoxic basin of the Pettaquamscutt Estuary on (a) 26 April and (b) 15 August 1989. Note that the Euglena peak overlaps the micro-oxic region where oxygen and hydrogen sulphide co-occur. Also note that the Euglena peak correlates with minor peaks in $\mathrm{O}_{2}$ (this figure), and Eh (Fig. 2)

feature of this chemical transition zone was that the chemoclines for methane, oxygen, and hydrogen sulphide were vertically offset from one another in both April and August. In both cases the methanocline occurred in the micro-oxic zone between the oxycline and the sulphidocline. The position of the major methanocline above the sulphidocline in the photic water column is reversed from the usual position of the methanocline below the sulphidocline reported for anoxic sediments. Such a reversal is clearly inconsistent with current sediment-based methane models.

High resolution profiles of methane, oxygen, and hydrogen sulphide revealed considerable fine structure that was highly correlated with a large peak in the biomass of the oxygenic alga Euglena proxima. Methane profiles collected in both April and August were charac- terized by a minor maximum at the base of the oxic layer about $0.75 \mathrm{~m}$ above $E \mathrm{~h}=0$, a minimum in the micro-oxic zone near $\mathrm{Eh}=0$, followed by a rapid increase to a major maximum about $0.75 \mathrm{~m}$ below the $\mathrm{Eh}=0$ boundary. Methane concentrations in both maxima increased between April and August while methane concentrations in the minimum decreased (Fig. 4). This indicates a dominance of methane-production above and below the $\mathrm{Eh}=0$ boundary and a dominance of methane-oxidation at or near the boundary. Active methane-oxidation would probably also be required to counterbalance an upward diffusive methane-flux so as to maintain the steep slope of the methanocline. The strong association of this methane minimum, the methanocline, and a small local maximum in oxygen within the biomass peak of Euglena proxima suggest that photosynthesis by this alga must provide the oxygen required to support such a major in-situ oxidation of methane.

\section{Fine structure of rates of potential methane-oxidation}

Potential methane-oxidation varied with depth in the April $2^{\circ} \mathrm{C}$ incubations (Fig. 5). The rates of potential methane-oxidation were low in the surface layer $\left(<2 \% \mathrm{~d}^{-1}\right)$, then rapidly increased in the oxycline to maximum levels of $9 \% \mathrm{~d}^{-1}$, then declined in deeper waters to levels of a few $\% \mathrm{~d}^{-1}$. This suggests that psychrophilic methane-oxidizers were concentrated in and just above the methanocline. An examination by transmission electron microscopy of thin sections of pelleted populations of the natural bacterioplankton obtained from $4 \mathrm{~m}$ showed the presence of cells with the characteristic ultrastructure of Type I methane-oxidizers (Davies \& Whittenbury 1970) in which the cytomembranes are arranged in stacked lamellae (Fig. 6) (Sieburth et al. 1987). Overlays of methane profiles before and after incubation indicated that it was possible for in situ methane-oxidation to control the steep slope and location of the primary methanocline and the persistent methane-minimum at the base of the oxycline. This assumes that in situ oxygen production and oxygen transport by physical processes is sufficient to supply the required oxygen in the southern basin of the estuary.

Potential methane-oxidation in August varied with depth, temperature and the length of the incubation period (Fig. 7a, b). The peak in potential methaneoxidation measured at $22^{\circ} \mathrm{C}$ in August was displaced below $E$ h $=0$, but showed a similar pattern to rates 


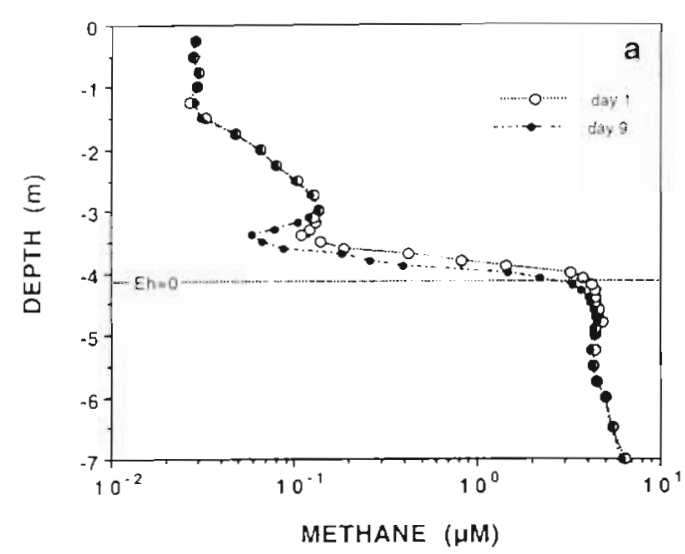

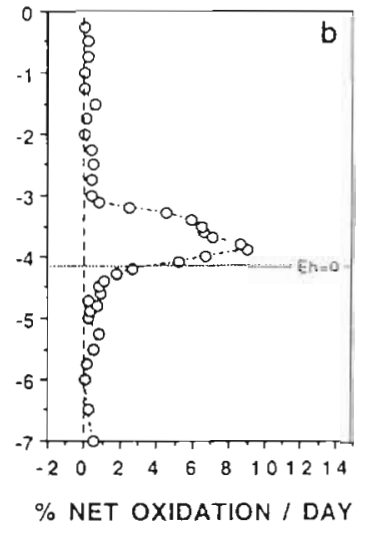

Fig. 5. Fine-scale structure and dynamics of methane in samples obtained 26 April 1989. Data are shown in (a) as overlays of concentration profiles collected at 2 times during incubation, Days 1 and 9, and in (b) as net methane oxidation rates (\% methane oxidation $\left.\mathrm{d}^{-1}\right)$. As discussed in text, incubations were at $\left(2^{\circ} \mathrm{C}\right)$ and show psychrophilic activity measured at $2{ }^{\circ} \mathrm{C}$ in April. Rates were low in the surface, increased to a maximum of $0.3 \mathrm{mM} \mathrm{d}^{-1}$ just below the Eh $=0$ boundary, then decreased at deeper depths to about $0.1 \mathrm{mM} \mathrm{d}^{-1}$. In terms of percent of ambient concentration per day, these rates increased from less than $1 \% \mathrm{~d}^{-1}$ in surface and deep waters to a peak of $14 \% \mathrm{~d}^{-1}$ just below the Eh $=0$ boundary. This peak in potential methane-oxidation rates corresponds to the region of net decease of in situ methane concentrations (Fig. $7 \mathrm{C}$ ) during the 4 mo between April and August profiles. This similarity of results between incubated bottles and in situ changes leaves little doubt that methane-oxidation was focused just below the $\mathrm{Eh}=0$ boundary.

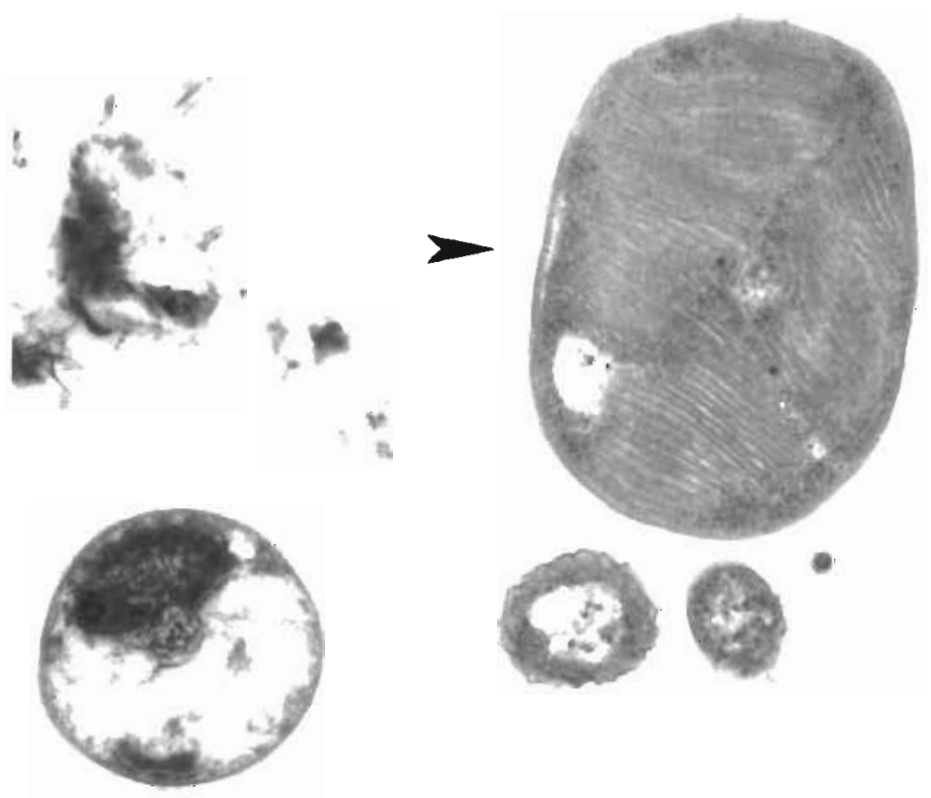

Fig. 6. A cell (arrowhead) from the natural population of bacterial plankton at $4 \mathrm{~m}$ in the methane minimum showing the characteristic ultrastructure of a Type I methane-oxidizer, in which the cytomembranes are arranged in stacked lamellae. The cell is approximately $0.5 \times 1.0 \mu \mathrm{m}$
The potential methane-oxidation rates measured in August at $2{ }^{\circ} \mathrm{C}$ were very different from those measured in August at $22^{\circ} \mathrm{C}$ or in April at $2{ }^{\circ} \mathrm{C}$ (Fig. $7 \mathrm{~b}$ ). During the first $4 \mathrm{~d}$ of incubation, potential methane-oxidation rates were very low in the surface layer, then gradually increased through the $E h=0$ boundary reaching a maximum of about $0.1 \mathrm{mM} \mathrm{d}^{-1}$ between 4.5 and $5.5 \mathrm{~m}$. This peak in potential methane-oxidation was located below that observed at $22^{\circ} \mathrm{C}$ in August and is in the same region as the major methane maximum. The vertical displacement of the peak in potential methane-oxidation measured at $2{ }^{\circ} \mathrm{C}$ below the peak measured at $22^{\circ} \mathrm{C}$ in August indicates that there are 2 populations of methane-oxidizers; a mesophilic population associated with the warmer waters above $4.2 \mathrm{~m}$ and a psychrophilic population persisting in the colder waters below $4.2 \mathrm{~m}$.

During Days 4 to 8 of the August incubations at $2^{\circ} \mathrm{C}$, methane concentration increased in all bottles from below the Eh $=0$ boundary, indicating a dominance of methane-production over methane-oxidation. Methane-production rates (indicated in Fig. $7 \mathrm{~b}$ as negative oxidation rates) reached about $0.1 \mathrm{mM} \mathrm{d}^{-t}$ in the region of the major methane maximum below the Eh $=0$ boundary. The high rates of potential methane-oxidation occurred in exactly the same region where methane concentrations were observed to increase in situ between April and August (Fig 7c). There is little doubt that the mid-water methane maximum below the $\mathrm{Eh}=0$ boundary was the result of dominance of in situ methane-production over in situ methane-oxidation. It is also very evident that this dominance of methaneproduction is dependent upon oxygenic photosynthesis. 

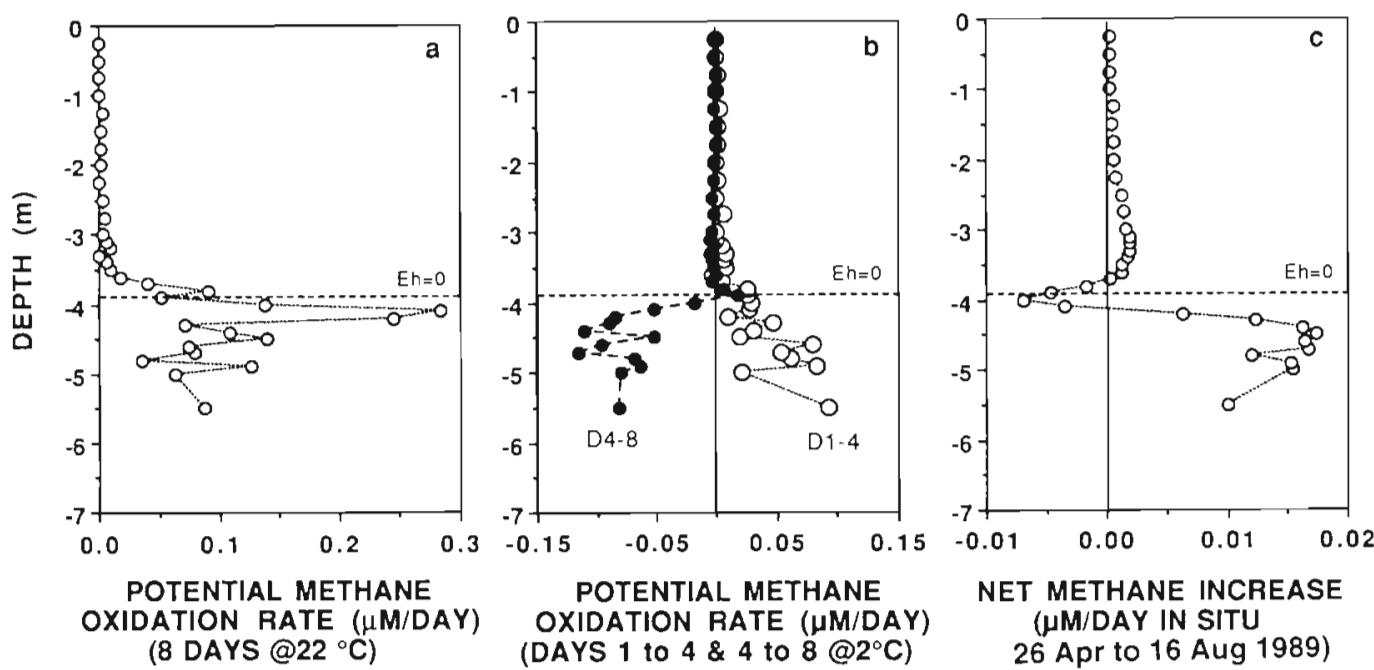

Fig. 7. Fine-scale structure and dynamics of methane in samples obtained 16 August 1989. (a) Samples used to obtain potential methane-oxidation rates at $22^{\circ} \mathrm{C}$ show a mesophilic oxidation peak just below Eh $=0$. (b) Samples used to obtain potential methane-oxidation rates at $2^{\circ} \mathrm{C}$ show a small net decrease below $\mathrm{Eh}=0$ over the total $8 \mathrm{~d}$ incubation, but when divided into two $4 \mathrm{~d}$ periods, Days 1 to 4 show positive values and therefore oxidation, while Days 4 to 8 show negative values and therefore methane production. (c) Net methane increase per day between the April and August profiles shown in Fig. 4. Except for the decrease in methane concentration at the minimum near $\mathrm{Eh}=0$, methane concentration increased in both the minor methane peak above and the major methane peak below the Eh $=0$ line

\section{Differential changes in the methanocline and sulphidocline}

Important differential changes occurred in the distribution of methane and hydrogen sulphide relative to seasonal changes in salinity (Fig. $8 \mathrm{~b}, \mathrm{c}$ ). The maximum salinity of low (<0.3 $\mathrm{mM}$ ) methane water decreased from 22 ppt in April to 12.5 ppt in August (Fig. 8b). This means that methane concentrations at a given salinity increased dramatically over the 4 mo period between April and August. Such increases cannot be explained by equal rates of upward mixing of salt and methane from deep water sources. Plots of methane versus salinity (Fig. 8b) were divided into 3 segments in both April and August, going from left to right: (1) a slowly increasing linear segment above the oxic-anoxic boundary, (2) a steeply increasing segment in the primary methanocline, and (3) a curvilinear section at and below the major methane maximum. In contrast, hydrogen sulphide was divided into 2 segments: (1) a slowly increasing linear segment above the Eh boundary, and (2) a steeply increasing segment below (Fig. 8c). Very different processes are controlling the methanocline and the sulphidocline.

Temperature-salinity (T-S) and methane-salinity plots were used to examine the potential role of physical processes in generating the pycnocline methane maximum. T-S plots from April and August were identical in deep water (i.e. low temperature, high salinity) and di- verged smoothly with increasing temperature (Fig. 9). The nearly linear nature of these T-S plots indicated that the changes in vertical structure were dominated by vertical mixing. T-S plots (Fig. 9) were also examined to determine whether the methane peak in the pycnocline could have been induced by lateral advection. In this system, $1 \mathrm{~m}$ sills greatly restrict such lateral advection in deep waters (below $4 \mathrm{~m}$ ), except in cases where high density water is advected up the channel, and intrudes into the deep basin along an isopycnal surface (Donaghay et al. 1992). In April, the T-S plot was linear at salinities above 12.5 pt except for a small dip at 25 ppt. This dip was most likely the result of a cold water intrusion. Interestingly, this dip corresponded to the salinity of the pycnocline peak in methane in April. In contrast, the August T-S plots showed no evidence of recent intrusions. The only inflection in the August T-S plot was a gentle curve at the pycnocline that would be expected from the higher rate of diffusion for temperature than salt. These results are consistent with the earlier evidence for the major methane maximum in the pycnocline being formed by in situ microbiological processes.

\section{DISCUSSION}

The case has been well made that the peak of dissolved methane in the oceanic pycnocline is particleasssociated (Scranton \& Brewer 1977, Burke et al. 1983, 

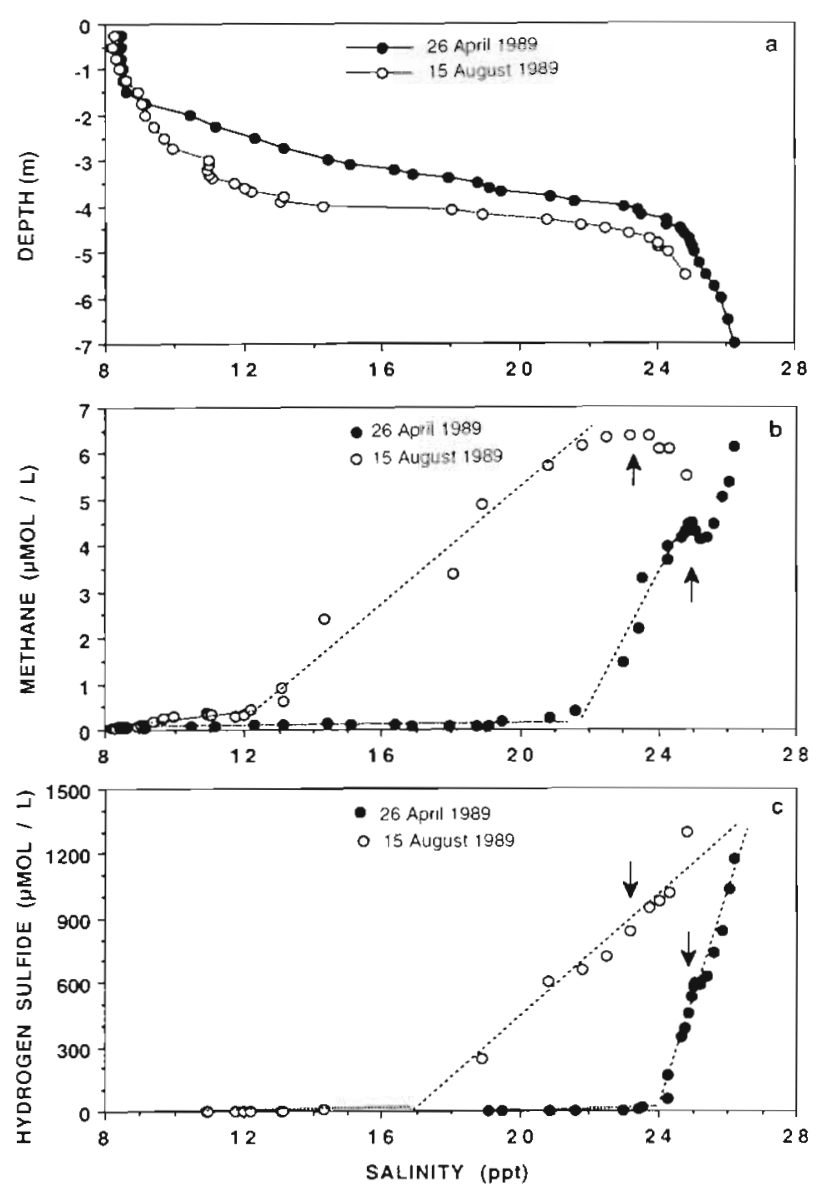

Fig. 8. (a) Seasonal changes in the vertical profiles of salinity and corresponding changes in the fine-scale distribution of (b) methane and (c) hydrogen sulphide plotted as functions of salinity. Data are shown for both April and August, 1989. The dotted lines have been drawn by eye to indicate reasonably linear regions of covariance of methane (b) and hydrogen sulphide (c) with salinity. The arrows in (b) and (c) denote the positions of the methane maxima. Note the dramatic increase in methane and hydrogen sulphide in low-salinity waters between April and August

Sieburth 1983, 1991). If there really is significant production and consumption of methane in the upper ocean, then it must be closely associated with the main site of primary production and in situ organic matter decay in the chlorophyll maximum of the pycnocline (cf. refs, in Sieburth 1988, 1991). In the southern anoxic basin of the Pettaquamscutt Estuary, the turbidity maximum also coindides with the fluorescence maximum. Methane maxima occur on either side of the central $\mathrm{Eh}=0$ boundary, while the methane minimum occurs at or near the $E h=0$ line where it is influenced by the oxygenic photosynthesis of Euglena proxima. The results of this study might be dismissed as characterizing a very specialized habitat. Other captive estuarine water columns that are permanently stratified are the land-

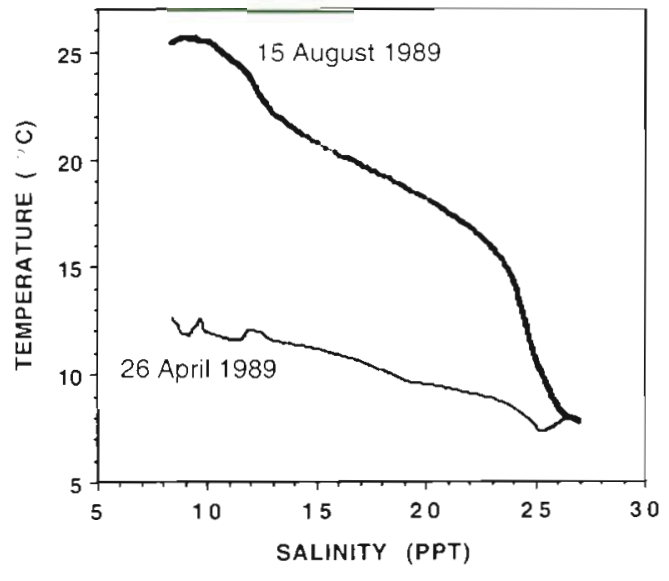

Fig. 9. Temperature-salinity diagrams for April and August, 1989

locked bays or oyster polls in Norway (Strøm 1936). An example is the Hunnenbunnen that is permanently anoxic and also contains a species of Euglena that occurs year round in the interface between the oxygenated and hydrogen sulphide containing layers that it controls (Braarud \& Føyn 1958). In addition there are other permanently stratified anoxic basins scattered throughout the world like Lago Faro, near Messina in Sicily (Genovese 1963, Trüper \& Genovese 1968). Other permanently stratified waters are the fjords like Lake Nitinat in British Columbia, Canada (Atkinson \& Richards 1967) and Framvaren in Norway (Lidstrom 1983) and larger bodies like the Black Sea (Reeburgh et al. 1991). In addition there are many seasonally stratified and anoxic water bodies like the coastal estuarine lakes on Åland, Finland (Lindholm 1982) and the Chesapeake Bay (Officer et al. 1984, Seliger et al. 1985, Malone 1991). To these water bodies the observations may apply directly. But the processes in well ventilated but stratified oceanic waters must be similar, the main difference being that dissolved oxygen is never exhausted and therefore the methane remaining from planktonic methane production is just a trace due to the concomitant oxidation of methane along with methane production.

Our estimates of vertical profiles of potential methaneoxidation are qualitatively similar to profiles of methane oxidation rate measured using ${ }^{14} \mathrm{C}$ methane addition techniques. For example, Scranton et al. (in press) found a maxima in ${ }^{14} \mathrm{C}$ methane oxidation rates in the redox boundary of the Pettaquamscutt Estuary in August 1991. This should not be surprising since it is well established that aerobic methane oxidation in aquatic systems tends to be focused in the redox boundary where both oxygen and methane are present (Large 1983). Although qualitatively similar, vertical profiles of methane-oxidation potential and profiles of methane 
oxidation rate measured using ${ }^{14} \mathrm{C}$ methane addition techniques can be expected to differ quantitatively from each other. ${ }^{14} \mathrm{C}$ methane addition techniques measure that methane-oxidation which can occur with the amount of dissolved oxygen in the sample at the time of collection. As a result they ignore the potential flux of oxygen by intrusion and oxygenic photosynthesis that could occur in situ over the incubation period. Therefore great care should be taken in making quantitative comparisons between the results of the 2 techniques.

Vertical profiles of potential methane-oxidation and profiles of methane ${ }^{14} \mathrm{C}$ methane oxidation rate may also differ quantitatively from true in situ oxidation rates. If true in situ aerobic methane-oxidation rates are dependent upon the concentration of methane and oxygen and the thermal types of methane oxidizers able to grow at in situ temperatures, changes in any of these variables between in situ and the bottle incubations will result in an under- or overestimation of true rates. For example, we have observed oxygen concentrations in the micro-oxic zone to vary between 0.1 and $4 \mathrm{mg}^{-1}$ depending upon the daily cycle of in situ oxygenic photosynthesis or the recent occurrence of a lateral intrusion of oxygenated water (Donaghay unpubl. data). Under such circumstances, potential methane oxidation rates measured at in situ temperatures may be a better estimate of average in situ rates than short-term ${ }^{14} \mathrm{C}$ incubations in the dark.

Our observations on the co-existence of oxygen and hydrogen sulphide is consistent with earlier observations in the OATZ of the Black Sea (Sorokin 1972), a marine lagoon (Ingvorsen \& Jørgensen 1979), marine sediments (Iversen \& Jørgensen 1985), and algal mats (Canfield \& DesMarais 1991). In our system, elevated potential methane-oxidation was measured in the reduced watercolumn coincident with the distribution of the oxygenic alga Euglena proxima. This lends support to the hypothesis that methane-oxidation would occur in the reduced zone due to an in situ production of oxygen by E. proxima (Sieburth 1987). This process is analogous to that previously described by King et al. (1990), in which oxygen produced by benthic photosynthesis had a marked effect on the diel profiles of methane in sediments. Just as this process would have a major impact on the magnitude of atmospheric fluxes of methane from the Everglades (Florida, USA), the algae in the dim pycnocline of stratified waters where a methane peak occurs (Sieburth 1988) may be playing a much larger role (Sieburth, 1991) than commonly accepted (Ciccereone \& Oremland 1988, Oremland 1988).

The central message of this report is embodied in Fig. 7. That a major methane-production that occurs in the pycnocline, whose vestigial remains in the open sea is just a very minor methane peak, is all but masked by a simultaneous and nearly equal in situ methane- oxidation. This is the same process that occurs in sealed containers of oxygenated seawater when added monomethylamine enriches $\mathrm{O}_{2}$-tolerant, anaerobic, methylotrophic methanogens whose reduced microniches are created by their $\mathrm{O}_{2}$-consuming aerobic bacterial consorts (Sieburth 1993). Long before dissolved oxygen becomes exhausted in the bulkwater and methane can accumulate in the headspace, a thin pellicle of methaneoxidizing bacteria that develops at the gas/liquid interface signals an appreciable but inapparent production of methane. This bacterial biomass of methane-oxidizers represents a secondary bacterial production that can be significant (Hessen \& Nygaard 1992) and voraciously grazed by bacterivores (Sieburth et al. 1987).

Methane-oxidizing bacterial cells were conspicuous in the preparations from $4 \mathrm{~m}$ in the methane minimum (Fig. 6). The cytomembranes of these cells occurred as the stacked lamellae of the Type I methanotrophs, but were distinct from those of the type species, Methylomonas methanica, and our oceanic species, Methylomonas pelagica (Sieburth et al. 1987). This is in agreement with our immunofluorescence study of estuarine and oceanic methane-oxidizers which indicated that estuarine cultures are distinct from oceanic cultures (Sieburth et al. 1993a). In our enrichment cultures (Sieburth 1993), methane accumulates only when dissolved oxygen becomes exhausted and methaneoxidation slows and ceases. The early oxic stage of the enrichment cultures apparently duplicates what occurs in the well-ventilated open sea, while the anoxic stage of enrichment cultures apparently duplicates what happens in poorly ventilated water bodies such as the anoxic basin in this study. When methylfluoride, an inhibitor of methane-oxidation, was added to methanogenic sediments, methane-oxidation was shown to consume over $90 \%$ of the methane produced (Oremland \& Culbertson 1992). This has been our contention of why the potential of the upper ocean methane cycle (Sieburth 1987, 1991) has not been recognized (Oremland 1988) for the major process that it is. This possibility is now being recognized (Hessen \& Nygaard 1992). Similar studies to that of Oremland \& Culbertson (1992) are indicated for the pycnocline of well stratified oxic and anoxic water columns.

Our observation of seasonal differences in the temperature optima for potential methane-oxidation is consistent with observations on the seasonal selection of thermal bacterial types in the adjacent waters of Narragansett Bay (Sieburth 1967). In this earlier work, the optimum temperature for growth of the dominant flora from $4.8^{\circ} \mathrm{C}$ water in April ranged from 8 to $20^{\circ} \mathrm{C}$, while that from $22.7^{\circ} \mathrm{C}$ water in September ranged from 17 to $30^{\circ} \mathrm{C}$. The April and August waters above $\mathrm{Eh}=0$ in this study had similar seasonal excursions in temperature and thus could be expected to have similar changes in 
the thermal types of methane-oxidizers. This is exactly what we found. The spread out particle layer in April had an active psychrophilic methane-oxidation that occurred largely above $\mathrm{Eh}=0$. This is because cold water conducive to psychrophiles occurred throughout the water column. When psychrophilic water temperatures only occurred below $4.2 \mathrm{~m}$ in August, psychrophilic methane methane-production and oxidation were restricted below $4.2 \mathrm{~m}$. There was only a thin layer of potential mesophilic methane-oxidation between the $\mathrm{Eh}=0$ line at $3.8 \mathrm{~m}$ and the psychrophilic methaneoxidation occurring below $4.2 \mathrm{~m}$. There is just a hint in the literature that psychrophilic methanogens could exist. Zeikus \& Winfrey (1976) found that methanogenesis was most active throughout the sampling year in Lake Mendota (Wisconsin, USA) sediments at their deepest station of $18 \mathrm{~m}$. In Zinder \& Brock (1978), their Fig. 2 indicates that methane production below $20^{\circ} \mathrm{C}$ was about $70 \%$ of the maximum from similar Lake Mendota sediments. Conversely samples from intertidal mud flats that would undergo episodic warming periods that would prevent psychrophile development (Seshadri \& Sieburth 1975), failed to show activity at $4^{\circ} \mathrm{C}$ (Vogel et al. 1982).

The existence of seasonal changes in methane oxidation potential at $2^{\circ} \mathrm{C}$ has important implications for measuring methane concentrations. In the original headspace method (Johnson et al. 1990), it was assumed that methane oxidation in the sample bottles does not alter the concentration during the time required for the bottles to equilibrate at $2^{\circ} \mathrm{C}(<1 \mathrm{~d})$. The August results reported here show that the persistence of psychrophiles are at variance with the summer tests of this assumption run during the development of this method. Our results indicate that significant errors can result in rate measurements if samples from waters containing psychrophiles such as the April and August samples are allowed to equilibrate for more than a few hours without the addition of a bactericidal agent. As a result, we have modified our collection procedure by adding mercury bichloride (Scranton et al. in press). Although such psychrophilic oxidation can cause errors in estimates of vertical profiles, the resulting errors are barely perceptible in systems with strong vertical concentration gradients.

The conventional model for microbial processes occurring in anoxic basins is largely based on studies in meromictic lakes. Although some $70 \%$ of the carbon produced in lakes never makes it to the bottom (Rudd \& Taylor 1980), this is ignored and organic matter decay including methanogenesis is believed to be restricted to anoxic sediments (Hanson 1980, Large 1983, Brock 1985, Reeburgh et al. 1991). In the ocean, the amount of primary production regenerated in situ is closer to 90\% (Eppley \& Peterson 1979, Angel 1984,
Fowler \& Knauer 1986, Karl et al. 1988, Cushman 1989). It is commonly believed that methane diffuses out of the benthos, mixes upward to help form the anoxic hypolimnion, and at the oxic-anoxic interface in the metalimnion methane is consumed by aerobic methane oxidizers with oxygen derived from vertical mixing. This conventional model is clearly inconsistent with the observations of a methane maximum in the pycnocline of the open ocean (Scranton \& Brewer 1977, refs. in Rudd \& Taylor 1980), with our microbiological data from stratified upper Chesapeake Bay (Sieburth 1993, Sieburth et al. 1993a, b), with that of stratified fjords (Lidstrom 1983, Ward et al. 1989) and with the data presented here.

An alternate model has been proposed (Sieburth 1991) to explain the methane maximum that occurs at the base of the photic zone in the lower parts of the chlorophyll a maximum regardless of whether it is lacustrine, estuarine or oceanic. In this published model, methane production can occur in anoxic microsites in the pycnocline of stratified waters where most of the primary production is regenerated in situ. This is analogous to the existence of the anaerobic process of sulphate reduction within reduced microniches of oxidized marine sediments (Jørgensen 1977). This model has been amplified to account for distinct subpopulations of methanogens observed in Chesapeake Bay (Sieburth 1993).

The beauty of our study site in the Pettaquamscutt basin is that the OATZ in the photic water column extends over a distance of $2 \mathrm{~m}$. This is in sharp contrast to the OATZ of sediments that occur on a scale of cm, and the OATZ in suspended particulates that occur on a scale of $\mathrm{mm}$. Similar processes probably occur in the OATZ's of suspended particulates, stratified estuaries, and anoxic sediments. Therefore the OATZ in our water column, with a greatly expanded scale that can be profiled and sampled on a fine scale, gives us an ideal site for studying the spatial relationships of the complex microbial assemblages and their processes in a typical photic OATZ. Such assemblages are much more difficult to study spatially in sediments, suspended particulates, and in estuaries with their horizontal motion. Our observations of potential methaneproduction and potential methane-oxidation in the headspace bottles with added oxygen clearly confirms the existence of oxygen tolerant methane-producers that coexist with their aerobic bacterial consorts, so that these process can coexist in the pycnocline, just as they do in methanogenic bacterial enrichments (Sieburth 1993)

The development of techniques for simultaneous profiling and sampling of the fine-scale biological, chemical, and physical structure of the stratified waters (Donaghay et al. 1992) played a key role in defining 


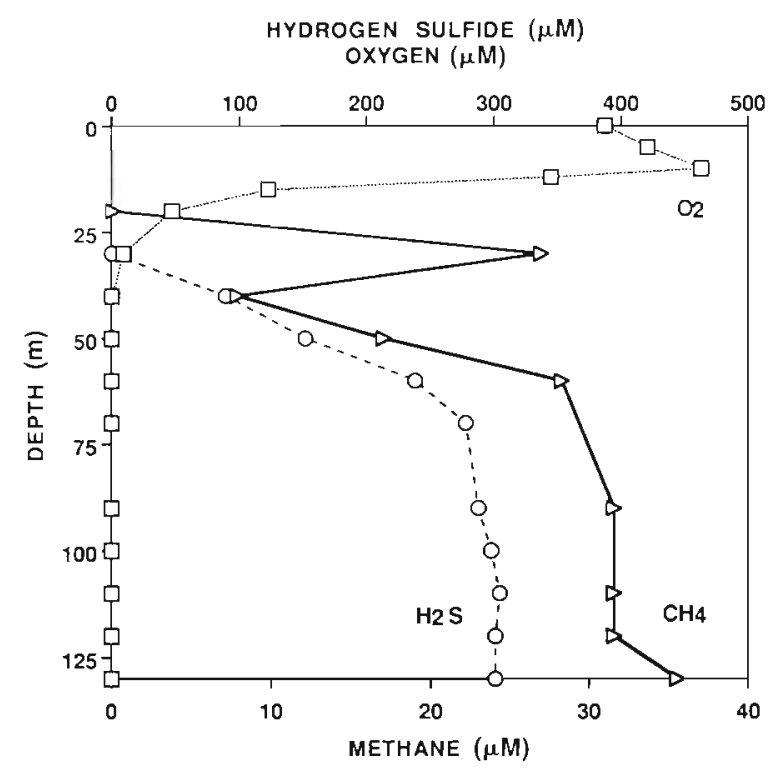

Fig. 10. Vertical distribution of oxygen, methane and hydrogen sulphide in Lake Nitinat, British Columbia, June 1965. Data redrawn from Atkinson \& Richards (1967). Note that this profile fortuitously picked up the minor methane maximum occurring in the oxic zone discussed in this paper, that is usually missed by coarse sampling, or ignored as an outlier

much of the structure we observed in the OATZ. For example, many of the primary features of the microoxic zone and methane and hydrogen sulphide maxima are sufficiently fine-scaled that they would be completely missed by conventional meter scale sampling, as discussed by Sieburth (1991) and Donaghay et al. (1992). Worse yet, they might appear as single data points that would be rejected as outliers. Such outliers are commonly observed in methane profiles near the Eh boundary (e.g. Atkinson \& Richards 1967, Ward et al. 1987, 1989). As an example, we have redrawn a profile from Atkinson \& Richards (1967), also obtained from an anoxic captive water column of a British Columbian fjord, and show it as Fig. 10. It is strikingly like the fine scale methane peak reported in this paper and includes both the minor and major methane maxima. We strongly suspect that the failure to define distinct water column methane minima and maxima as well as a thin zone of oxygenic algae in the OATZ of other studies, may be the result of sampling on too coarse a scale. Final resolution of the current controversy over the existence of significant upper ocean methane and hydrogen sulphide cycles (Sieburth 1991) will depend upon applying high resolution techniques to a diversity of systems in an effort to determine the generality of our findings.

We cannot emphasize too strongly that the planktonic methanogens in the water column are very dis- tinct from benthic methanogens (Sieburth 1993). We have hypothesized that methanogens in the ocean are mainly planktonic in nature and that most depend upon their aerobic bacterial consorts to create reduced microniches wherein they can function and thrive. We go on to speculate that the nearshore benthos where methanogens occur in anoxic sediments is really an environment where the high suphide concentrations exclude the usual aerobic consorts of planktonic methanogens. If this is correct, then the Eh potential of the habitat of planktonic methanogens must be less than the -200 to $-300 \mathrm{mV}$ that occur in pure cultures (Mah et al. 1977). Psychrophilic methane-production was observed to occur in this study from $-300 \mathrm{mV}$ up to $\mathrm{Eh}=0$. This would include methanogens that can grow on the Regimens 2 and 3 of Sieburth (1993). If the minor methane maximum is the result of in situ production, then the methanogens occurring from 0 to $+100 \mathrm{mV}$ could be the $\mathrm{H}_{2} \mathrm{~S}$-sensitive methanogens cultured in Regimen 1 of Sieburth (1993). A much higher Eh potential of the planktonic methanogens is also indicated by the methanocline posed above the sulphidocline both in our data (Fig. 4) and that in Lake Nitinat (Fig. 10 redrawn from Atkinson \& Richards 1967). The mechanisms in the water column that control the sulphidocline must be very different from those that control the methanocline (Fig. 8). The mechanisms responsible for the inverted position of the methanocline and sulphidocline in the water column in contrast to that in the sediment deserve further study.

Acknowledgements. This project was initiated under the University of Rhode Island Sea Grant College Program through grant M/PD 8703, and was supported in part by the Biological Oceanography program of the National Science foundation through grants OCE-8710085, and OCE-8911367, the U.S. Environmental Protection Agency through AERL9005, and the Melanitta Fund. The development of the high resolution profiling system was supported by ONR grants. The technical assistance of Paul W. Johnson with the Euglena proxima counts and the micrograph in Fig. 6, as well as the oxygen and Eh determinations is gratefully acknowledged, as is the technical assistance of Kenneth M. Johnson with the methane analysis and other chemical determinations.

\section{LITERATURE CITED}

Angel, M. V (1984). Detrital organic fluxes through pelagic ecosystems. In: Fasham, M. J. R. (ed.) Flows of energy and materials in aquatic ecosystems: theory and practice Plenum Press, New York, p. 475-516

Atkinson, L. P., Richards, F. A. (1967). The occurrence and distribution of methane in the marine environment. Deep Sea Res. 14: 673-684

Braarud, T., Føyn, B. (1958). Phytoplankton observations in a brackish water locality of south-east Norway. Nytt. Mag. Bot. 6: 47-73

Brock, T D. (1985). A eutrophic lake, Lake Mendota, 
Wisconsin. Ecological studies, Vol. 55. Springer Verlag, New York, p. 308

Burke, R. A. Jr, Reid, D. F., Brooks, J. M., Lavoie, D. M. (1983). Upper water column methane geochemistry in the eastern tropical North Pacific. Limnol. Oceanogr. 28: 19-23

Canfield, D. E., DesMarais, D. J. (1991). Aerobic sulfate reduction in microbial mats. Science 251. 1471-1473

Ciccerone, R. J., Oremland, R. S. (1988). Biogeochemical aspects of atmospheric methane. Global geochem. Cycles 2: $299-327$

Cline, J. D. (1969). Spectrophotometric determination of hydrogen sulfide in natural waters. Limnol. Oceanogr. 14 : $454-458$

Cushman, D. H. (1989). A difference in structure between ecosystems in strongly stratified waters and those that are only weakly stratified. J. Plankton Res. 11: 1-13

Cynar, F. J., Sieracki, M. E., Sieburth, J. McN. (1985). Estimating plankton populations with the Apple II. BioSci. 35 $652-655$

Cynar, F. J., Yayanos, A. A. (1991). Enrichment and characterization of a methanogenic bacterium from the oxic upper layer of the ocean. Curr. Microbiol. 23: 89-96

Dangeard, P.-A. (1901). Recherches sur les Eugléniens. Le Botaniste 8: 97-357

Davies, S. L., Whittenbury, R. (1970). Fine structure of methane and other hydrocarbon-utilizing bacteria. J. gen. Microbiol. 61: 227-232

Donaghay, P. L., Rines, H. M., Sieburth, J. McN. (1992) Simultaneous sampling of fine scale biological, chemical, and physical structure in stratified waters. Arch Hydrobiol. Beit. 36: 97-108

Eppley, R. W., Peterson, B. J. (1979). Particulate organic matter flux and planktonic new production in the deep ocean. Nature 282: 677-680

Fowler, S. W., Knauer, G. A. (1986). Role of large particles in the transport of elements and organic compounds through the oceanic water column. Prog. Oceanogr 16 $147-194$

Gaines, A. G. Jr (1975). Papers on the geomorphology, hydrography, and geochemistry of the Pettaquamscutt River estuary, Ph.D. thesis, Univ. of Rhode Island, Kingston

Gaines, A. G. Jr, Pilson, M. E. Q. (1972). Anoxic water in the Pettaquamscutt River. Limnol. Oceanogr. 17:42-49

Genovese, S. (1963). The distribution of the $\mathrm{H}_{2} \mathrm{~S}$ in the Lake of Faro (Messina) with particular regard to the presence of 'red water' In: Oppenheimer, C. H. (ed.) Symposium on marine microbiology. C.C. Thomas, springfield, p. $194-204$

Hanson, R. S. (1980). Ecology and diversity of of methylotrophic organisms. Adv. appl. Microbiol 26: 3-39

Hessen, D., Nygaard, K. (1992). Bacterial transfer of methane and detritus: implications for the pelagic carbon budget and gaseous release. Arch. Hydrobiol. Beih. 37: 139-148

Iversen, N., Jørgensen, B. B. (1985). Anaerobic methane oxidation rates at the sulfate-methane transition in marine sediments from Kattegat and Skagerrak (Denmark). Limnol. Oceanogr. 30: 944-955

Ingvorsen, K., Jørgensen, B. B. (1979). Combined measurement of oxygen and sulfide in water samples. Limnol. Oceanogr. 24:390-393

Johnson, K. M., Hughes, J. E., Donaghay, P. L., Sieburth, J. McN. (1990). Bottle-calıbration static headspace method for the determination of methane dissolved in seawater Anal. Chem. 62: 2408-2412

Jørgensen, B. B. (1977). Bacterial sulfate reduction withm reduced microniches of oxidized marine sediments. Mar. Biol. 41.7-17
Karl, D. M., Knauer, G. A., Martin, J M. (1988). Downward flux of particulate organic matter in the ocean: a particle decomposition paradox. Nature 332: 438-441

King, G. M. (1984) Metabolism of trimethylamine, choline, and glycine betaine by sulfate-reducing and methanogenic bacteria in marine sediments. Appl. environ. Microbiol. 48: 719-725

King, G. M., Klug, M. J., Lovely, D. R. (1983). Metabolism of acetate, methanol and methylated amines in intertidal sediments of Lowes Cove, Maine. Appl environ. Microbiol. 45: 1848-1853

King, G. M., Roslev, P., Skovgaard, H. (1990). Distribution and rate of methane oxidation in sediments of the Florida Everglades. Appl. environ. microbiol. 56: 2902-2911

Large, P. J (1983). Methylotrophy and methanogenesis. Aspects of microbiology, Vol. 8. Am. Soc. Microbiol., Washington, DC, p. 88

Lidstrom, M. E. (1983). Methane consumption in Framvaren, an anoxic marine fjord. Limnol. Oceanogr. 28: 1247-1251

Lindholm, $T$ (1982). Dynamics of hydrography and primary production in three stratified coastal lakes on Aland (SW Finland). Acta. Acad. Aboensis, Ser. B. 42: 1-75

Mah, R. A., Ward, D. M., Baresi, L., Glass, I L. (1977). Biogenesis of methane. A. Rev. Microbiol. 31: 309-341

Malone, T C. (1991). River flow, phytoplankton production and oxygen depletion in Chesapeake Bay. In: Tyson, R. V., Pearson, T. H. (eds.) Modern and ancient continental shelf anoxia. Geol. Soc. Spec. Pub. No. 59, London, p. 83-93

Miller, B. T (1972). The phytoplankton and related hydrography in the south basin of the Pettacuamscutt River. M.Sc. thesis, Univ. of Rhode Island, Kingston

Officer, C. B., Biggs, R. B., Taft, J. L., Cronin, L. E., Tyler, M. A., Boynton, W. R. (1984). Chesapeake Bay anoxia: origin, development and significance. Science 223: 22-27

Oremland, R. S. (1979). Methanogenic activity in plankton samples and fish intestines: a mechanism for in situ methanogenesis in oceanic surface waters. Limnol. Oceanogr. 24: 1136-1141

Oremland, R. S. (1988). Bigeochemistry of methanogenic bacteria. In: Zhender, A. J. B. (ed.) Biology of anaerobic microorganisms. John Wiley \& Sons, Inc., New York, p. 641-705

Oremland, R. S., Culbertson, C. W. (1992). Importance of methane-oxidising bacteria in the methane budget as revealed by the use of a specific inhibitor. Nature 356: $421-423$

Oremland, R. S., Marsh, L. M., Polcin, S. (1982). Methane production and simultaneous sulfate reduction in anoxic salt marsh sediments. Nature 296: 143-145

Reeburgh, W. S., Ward, B. B., Whalen, S. C., Sandbeck, K. A., Kilpatrick, K. A., Kerkhol, L. J. (1991). Black Sea methane geochemistry. Deep Sea Res. 38: S1189-S1210

Rudd, J. W. M., Taylor, C. D. (1980). Methane cycling in aquatic environments. Adv. aquat. Microbiol 2: 77-150

Schlegel, H. G., Jannasch, H.W. (1981). Prokaryotes and their habitats. In: Starr, M. P., Stolp, H., Trüper, H. G. Balows, A., Schlegel, H. G. (eds.) The procaryotes, Vol. 1. Springer Verlag, Berlin, p. 43-82

Scranton, M. I., Brewer, P. G. (1977). Occurrence of methane in the near-surface waters of the western subtropical North Atlantic. Deep Sea Res. 24: 127-138

Scranton, M. I., Crill, P., deAngelis, M., Donaghay, P. L., Sieburth, J. McN. (in press) The importance of episodic events in controlling the flux of methane from an anoxic basin. Global biogeochem. Cycles

Seliger, H. H., Boggs, J. A., Biggley, W. H. (1985). Catastrophic anoxia in the Chesapeake Bay in 1984. Science, 228: $70-73$ 
Seshadri, R., Sieburth, J. McN. (1975). Seaweeds as a reservoir of Candida yeasts in inshore waters. Mar. Biol. 30 105-117

Sieburth, J. McN. (1967). Seasonal selection of estuarine bacteria by water temperature. J. exp. Mar. Biol. Ecol. 1: $98-121$

Sieburth, J. McN. (1983). Microbiological and organicchemical processes in the surface and mixed layers. In: Liss, P. S., Slinn, W. G. N. (eds.) Air sea exchange of gases and particles. D. Reidel Publ. Co., Dordrecht, p. 121-172

Sieburth, J. McN. (1987). Contrary habitats for redox-specific processes: methanogenesis in oxic waters and oxidation in anoxic waters. In: Sleigh, M. A. (ed.) Microbes in the sea. Ellis Horwood L.td, Chichester, p. 11-38

Sieburth, J. McN. (1988). The nanoalgal peak in the dim oceanic pycnocline: is it sustained by microparticulates and their bacterial consortia? In: Agegian, C. R. (ed.) Biogeochemical cycling and fluxes between the deep euphotic zone and other oceanic realms. NOAA National Undersea Research Program, Rockville, MD, Research Report 88-1: 101-130

Sieburth, J. McN. (1991). Methane and hydrogen sulfide in the pycnocline: a result of tight coupling of photosynthetic and 'benthic' processes in stratified waters. In: Rogers, J. E., Whitman, W. B. (eds.) Microbial production and consumption of greenhouse gases: methane, nitrogen oxides, and halomethanes. Am. Soc. Microbiol., Washington, DC, p. $147-174$

Sieburth, J. McN. (1993). C 1 bacteria in the water column of Chesapeake Bay, USA. I. Distribution of 3 sub-populations of $\mathrm{O}_{2}$-tolerant, obligately anaerobic, methylotrophic methanogens that occur in microniches reduced by their bacterial consorts. Mar. Ecol. Prog. Ser. 95: 64-80

Sieburth, J. McN. (in press). $C_{1}$-bacteriostats culture stable consortia of methane cycle and sulfate-reducing bacteria, by acting as surrogate marine algae. In: Wiessner, W. (ed.) Algae, man and environment. Chapman and Hall, New York

Sieburth, J. McN., Johnson, P. W., Eberhardt, M. A., Sieracki, M. E., Lidstrom, M., Laux, D. (1987). The first methaneoxidizing bacterium from the upper mixing layer of the deep ocean: Methylomonas pelagica sp. nov. Curr. Microbiol. 14: 285-293

Sieburth, J. McN., Johnson, P. W., Church, V. M., Laux, D. C. (1993a). $C_{1}$ bacteria in the water column of Chesapeake

This article was submitted to the editor
Bay, USA. III. Immunologic relationships of the type species of marine monomethylamine- and methaneoxidizing bacteria to wild estuarine and oceanic isolates. Mar. Ecol. Prog. Ser. 95: 91-102

Sieburth, J. McN., Johnson, P. W., Macario, A. J. L., Conway de Macario, E. (1993b). $C_{1}$ bacteria in the water column of Chesapeake Bay, USA. II. The dominant $\mathrm{O}_{2}$ - and $\mathrm{H}_{2} \mathrm{~S}$ tolerant methylotrophic methanogens, coenriched with their oxidative and sulphate reducing bacterial consorts, are all new immunotypes and probably include new taxa. Mar. Ecol. Prog. Ser. 95: 81-89

Sorokin, Yu. I. (1972). The bacterial populations and the processes of hydrogen sulfide oxidation in the Black Sea. J. Cons. int. Explor. Mer 34: 423-454

Sowers, K. R., Ferry, J. G. (1983). Isolation and characterization of a methlotrophic marine methanogen, Methanococcoides methylutens gen. nov. sp. nov. Appl. environ. Microbiol. 45: 684-690

Strøm, K. M. (1936). Land-locked waters. Skr. Vidensk. Akad. Oslo 1. 7, $85 \mathrm{p} .+9 \mathrm{pl}$.

Trüper, H. G., Genovese, S. (1968). Characterization of photosynthetic sulfur bacteria causing red water in Lake Faro (Messina, Sicily). Limnol. Oceanogr. 13: 225-232

Tyler, M. A., Seliger, H. H. (1989). Time scale variations of estuarine stratification parameters and impact on the food chains of the Chesapeake Bay, In: Neilson, B. J., Kuo, A., Brubaker, J. (eds.) Estuarine circulation. Humana Press, Clifton, p. 201-233

Vogel, T. M., Oremland, R. S., Kvenvolden, K. A. (1982). Lowtemperature formation of hydrocarbon gases in San Francisco Bay sediment (California, U.S.A.). Chem. Geol. 37: $289-298$

Ward, B. B., Kilpatrick, K. A., Novelli, P. C., Scranton, M. I. (1987). Methane oxidation and methane fluxes in the ocean surface layer and deep anoxic waters. Nature 327: $226-229$

Ward, B. B., Kilpatrick, K. A., Wopat, A. E., Minnich, E. C., Lidstrom, M. E. (1989). Methane oxidation in Saanich Inlet during summer stratification. Cont. Shelf Res. 9: 65-75

Zeikus, J. G., Winfrey, M. R. (1976). Temperature limitation of methanogenesis in aquatic sediments. Appl. environ. Microbiol. 31: 99-107

Zinder, S. H., Brock, T. D. (1978). Production of methane and carbon dioxide from methane thiol and dimethyl sulfide by anaerobic lake sediments. Nature 273: 226-228

Manuscript first received: April 14, 1993

Revised version accepted: June 22, 1993 